the dynamic fatigue life and cracks of rubber vibration isolator. This particular Memoir is well printed, and the English translations are reasonably good, the papers, where appropriate, being illustratod with ample diagrams and reproductions of original photographs.

\section{U.K. Central X-ray Library}

THE first central library of X-ray films in Britain is to be set up by the Faculty of Radiologists in London, with the aid of a grant from the Wellcome Trust. The object of the library is to gather in one place a wide range of $\mathrm{X}$-ray studies of common and rare diseases, since recognition of an uncommon disease may depend on the knowlc dge gained from similar cases. Radiological techniques are of special importance in providing knowledge about the condition of inaccessible organs during life. A number of major advances in medical knowledge have already rosulted from radiological investigations. In the past, clinicians and research workers investigating rare diseases have had to gather X-ray examples from different hospitals throughout Britain. The new central library will enable a quick comparison to be made of a crosssection of previous investigations of a particular disease. The Wellcome Trust was created by the will of the late Sir Henry S. Wellcome, who died in 1936. In the past six years it has made grants totalling more than $£ 4$ million for work in medical and allied sciences.

\section{Nucleonic Instrument Modules}

A NEW booklet which describes the Wells series of Nucleonic Instrument Modules is now available from EMI Electronics, Ltd. (The Wells Series of Nucleonic Instrument Modules. Pp. 12. Hayes, Middx.: EMI Electronics, Ltd., 1964). This series of all-transistor modular units can be assombled in any order to provide a wide variety of facilities in the nucleonic instrument field. Individual instruments which can be assembled from the modules include a simple or an automatic counting system, a $\gamma$-spectrometer, and a simple or a comprehensive ratemeter for Geiger-Müller and scintillation counter probes. They can be either mains or battery operated. Plug-in printed circuit boards facilitate servicirg and a special panel can be supplied if required so that the modules can fit into a standard 19-in. rack. The range of modules at present available consists of a linear amplifier, a single channol pulse-height analyser, a linear rate-meter covering $0-5 \mathrm{kc} / \mathrm{s}$ in six linear ranges, a scannirg recorder for use with the analyser ard rate-meter, a five-decade scaler with a resolution time of 1 usec, $\gamma$-probes and a $\gamma$-spectrometer. The range is to be extended.

\section{The Geochemistry of the Rarer Elements}

IN 1956 the U.S.S.R. Academy of Sciences established a specialist institute for the investigation of the mineralogy and geochemistry of the rare elements (I.M.G.R.E.), from which an extensive flow of publications has since been maintained. Several of its works, including moncgraphs on beryllium, selenium and tellurium, have been translated into Er.glish under the $x$ gis of the Geochemical Society. The latest and most important publication of I.M.G.R.E., sponsored jointly by the Academy and by the Stato Geological Committee, comprises three encyclopædic volumes designed to summarize all aspects of the distribution of certain rarer elements in the lithosphere and hydrosphere (Geokhimiya, Mineralogiya $i$ Geneticheskie Tipy Mestorozhdenii Redkikh Elementov (Geochemistry, Mineralcgy and Genetic Types of Deposit of the Rare Elements), 1. Edited by K. A. Vlasov. Pp. 688. Moscow: "Nauka", 1964. Price 4r. 43k.). The first volume is concerned in successive chapters with the geochemistry of the elements $\mathrm{Li}, \mathrm{Rb}, \mathrm{Cs}, \mathrm{Be}, \mathrm{Sr}, \mathrm{Sc}, \mathrm{Y}, \mathrm{TR}$, $\mathrm{Zr}, \mathrm{Hf}, \mathrm{Nb}, \mathrm{Ta}, \mathrm{Cd}, \mathrm{Ca}, \mathrm{In}, \mathrm{Tl}, \mathrm{Ge}$, Se, Te and Re (the actinides and the noble metals are outside the Institute's province). A great deal of new material has been incor- porated and the work is likely to remain the most important reference text in its ficld for a good many years. A second volume, to be published in July 1964 , will deal in detail with the mineralcgy of these elements, describing the 415 relevant mineral species, of which 26 were first recognized in tho laboratories of I.M.G.R.E. The third part of the work is concerned with field geology, paragenetic relationships, and classification of deposits, and will appear early in 1965. Altegether about 80 geochemists have beon er gaged in this largo-scale co-operative enterprise, on the first results of which Dr. Vlasov and his colleagues are to be warmly congratulated.

\section{Milk Iron in a Lactating Marsupial}

I. Kaldor and Eric Ezekiel, of the Dopartment of Physiology, University of Western Australia, have administered, in the lactating quokka (Setonix brachyurus), parentoral iron, as forrous ammonium sulphate solution, in an attempt to raise the milk iron (Austral. J. Exp. Biol., 42, Part 1; Fobruary 1964). Following a single large intraperitoneal dose, a rise in milk iron occurred within two hours. There was, however, no clear relationship between the rise and the amount of iron injected and there was reason to believe that the rise had been associated with unphysiologically high plasma iron concentrations. During continuous intravenous infusion of iron at controlled rates, plasma iron was elevated to maximal levels not exceeding plasma total ironbinding capacity and, under these conditions, no significant alteration in milk iron occurred within four hours. A progressive and statistically significant rise in total plasma iron binding capacity which occurred during intravenous infusion of iron was probably the manifestation of a redistribution of intra- and extra-vascular transferring in response to the need for more rapid removal of iron from the plasma.

\section{Post-doctoral Fellowships in Neoplastic Growth}

The Jane Coffin Childs Momorial Fund for Modical Research supports investigations in the fundamental aspects of neoplastic growth, and awards post-doctoral followships to candidates of outstanding potential in the same field. Applications for grants-in-aid are reviewed by the Board of Scientific Advisers and the Board of Managers of the Fund three times a year, in the autumn, winter and spring. Final dates for receipt of applications are September 1, November 1 and March 1. Fellowship applications are reviewed at the winter meoting of the Fund, tho final date for applications being October 1 of each year. Grants-in-aid and fellowships are not restricted to United States citizens, but fellowship programmes should involve scientific interchange with the United States. Further information can be obtained from the Office of the Assistant Director, Jane Coffin Childs Memorial Fund for Medical Research. 333 Cedar Street, New Haven, Connecticut 06510.

\section{National Amateur Astronomical Convention}

The Rank Taylor Hobson and Ratcliffe Collego Astronomical Societies are holding their second national amateur astronomical convention at Ratcliffe College, Leicester, during September 4-6. Among the loctures which have been arranged are: "Polar Wander and Continental Drift", by Dr. H. C. King, curator of the London Planetarium; "Radio Telescopes and Radio Observation", by Mr. D. Barber, Royal Radar Establishment, Groat Malvern; "Cosmology and Space Rosearch", by Dr. R. C. Jennison, Jodrell Bank Experimental Station; "The Astrophysies of Visual Binaries", by Dr. D. Jones, Royal Greenwich Observatory; "Solar Activity", by Dr. J. Reed, acting director of Dunsink Observatory, Dublin; "Current Work at the Royal Observatory, Edinburgh", by Dr. P. Fellgett, Royal Observatory, Edinburgh; and 